DOI: $10.2478 /$ pof-2018-0018

VOLUME 10, ISSUE 2, 2018

ISSN: $2036-5438$

\title{
History of a (Limited) Success: Five Points on the Representativeness of the Committee of the Regions \\ by
}

Giuseppe Martinico*

Perspectives on Federalism, Vol. 10, issue 2, 2018 


\section{Abstract}

This article briefly explores the reasons why the Committee of the Regions (CoR) has only partially accomplished its representative function. It is divided into three parts. In the first part I argue that the ambiguous nature of the CoR is the consequence of the polysemous notion of 'region' in EU law (Palermo, 2005) and of the very heterogeneous approach to the 'federal issue' in Europe. In the second part of the article I look at the recent developments that have given the CoR new powers, for instance in light of Art. 263 TFEU in order to defend its own prerogatives and Art. 8 of Protocol No 2 on the application of the principles of subsidiarity and proportionality. This will be done by looking at a recent resolution of the CoR on a proposal made by the EU Commission to amend Regulation (EU) No 1303/2013.

Finally, I deal with some proposals that have been advanced to strengthen the role of the CoR, and their feasibility.

\section{Key-words}

regions, Committee of the Regions, subsidiarity, Lisbon Treaty 


\section{Goals and Structure of the Research}

This article briefly explores the reasons why the Committee of the Regions ${ }^{\mathrm{I}}$ (CoR) has only partially accomplished its representative function. In this respect the rhetoric about the CoR as a Third Chamber or a Senate of the Regions at the EU level is very telling of the debate about the ambiguities surrounding this body. However, this work is not about the desirability of a tricameral solution at the EU level, rather in this piece I try to explore some of the options proposed to reinforce the role of the CoR. In recent years lawyers have not paid much attention to the functioning of the Committee apart from a remarkable piece of work by Vandamme in 2013. Going beyond the legal literature it can be seen how scholars have presented different accounts of the work of the Committee itself. According to some scholars the non-binding nature of its opinions does not give CoR any possibility of substantially changing the direction already given to the legislative act (Simonato 2013), while others have stressed the important cooperation between the Commission and the CoR, triggered as a result of these consultative procedures (Neshkova 2010).

This article is divided into three parts. In the first part I argue that the ambiguous nature of the CoR is the consequence of the polysemous notion of 'region' in EU law (Palermo 2005) and of the wide ranging and heterogeneous approach to the 'federal issue' in Europe. An explanation for this is that regions do not have a common position, and this is, again, the product of constitutional heterogeneity at the national level (see Gamper 2005; Russo 2012), where regions have a strong constitutional status in some legal orders, while this is not the case in other contexts. This also explains the difficulties of the CoR and, to a certain extent at least, the reasons why the Conference of European Regional Legislative Assemblies (CALRE) was launched in 1997. II This is a confirmation of the existence of a sort of two speed (regional) European Union (legislative regions versus administrative regions, two actors with different priorities and interests). Indeed, according to authors like Skoutaris, one of the reasons that still justifies the existence of what Ipsen (1966) called Landesblindheit is that federalism is an 'uncommon principle in European constitutional law' (Skoutaris 2012).

In the second part of the article I look at the recent developments that have given the CoR new powers, for instance in light of Art. 263 TFEU, in order to defend its own 
prerogatives, ${ }^{\text {III }}$ and Art. 8 of Protocol No 2 on the application of the principles of subsidiarity and proportionality. ${ }^{\text {IV }}$ This will be done by looking at a recent resolution of the CoR on a proposal made by the EU Commission to amend Regulation (EU) No $1303 / 2013$.

Finally, I deal with some proposals that have been advanced to strengthen the role of the CoR, and examine their feasibility.

\section{The Idea of the Committee of the Regions as a Third Chamber in the EU}

Scholars interested in EU studies have been debating whether the EU is a bicameral system (see Norton 2006) for a long time, and even after the entry into force of the Lisbon entry research has suggested that the European Parliament and the Council are not put on equal footing in the co-decision procedure (Hagemann and Høyland 2010). Against this background some scholarly works have sometimes treated the EU as a sort of tricameral system, by describing either the national parliaments (although in 'virtual' terms, Cooper, 2012), after the introduction of the Early Warning System (EWM) or the Committee of the Regions, as the third chamber of the Union. The CoR itself has sometimes referred to this idea in some official documents, this is the case, for instance, of the White Paper on multilevel governance adopted by the Committee on 16 June 2009. ${ }^{\mathrm{V}}$ Drawing from this, and other documents, scholars have described this idea in the following terms:

'The CoR is saying that, given the representative and political mandate of its members, it cannot simply be considered as a technical consultative body but it must be given a central role in EU policy-making as is appropriate for a representative, political chamber. It is saying, even more boldly, that the CoR is the third representative chamber of the Union after the chamber that represents the citizens of the Union (the Parliament) and the chamber that represents the Member States of the Union (the Council). Multilevel governance, thus, acquires a more precise meaning, because the levels to be considered in the future Europe cannot be just two, but three and more' (Piattoni 2013).

However, on closer inspection there is no comparative model behind this reference to tricameralism. In other words, those (including the CoR itself) who speak of the Committee as a third chamber of the EU were not advocating the transplant of some 
tricameral experience, present elsewhere, into the supranational context. The origin of this idea is therefore connected to a particular political atmosphere that characterised the EU after c.1988 and belongs to a time which was very rich in political announcements. This article explores the main reasons that have led to such a scenario focusing in particular on five factors.

The first factor is the polysemous notion of 'region' in the EU. As Conzelmann wrote, this concept is not necessarily tied to any sort of constitutional or administrative structure but is rather a socially constructed concept: A region emerges where actors are coming together on the basis of geographic proximity and a shared problem or opportunity' (Conzelmann 2008). In this sense we can say that the composition of the Committee does not correspond exactly to the notion of Region adopted by the NUTS ('Nomenclature of territorial units for statistics'), because of the lack of correspondence between the legal notion and the economic notion of Region. This issue is also connected with the ambiguous terminology employed in EU cohesion policies, where terms like 'region' or 'regionalism' are used in several contexts: regional community, regional society, regionstate, regional complex (Hettne and Söderbaum 2002).

Nevertheless, it must be said that in the past scholars have noticed a process of (partial) adaptation of the internal territorial configuration of the legal order to the criteria used by the NUTS to identify the regions (Brusis 2002). However, these initiatives have been only partially accepted in the new Member States (for the difficulties connected with the affirmation of federalism in the new Member States, see Palermo 2012).

These considerations are related to the second reason behind the limited success of the Committee, namely the constitutional diversity present at the national level. Indeed, As Gamper (2005) and Palermo (2005) have argued some EU Member State do not have a federal or regional structure, and in fact many of them barely know forms of administrative decentralisation. This is what Skoutaris meant when defining federalism as the '(un)common constitutional principle' (Skoutaris 2012). This is no mere detail, since one of the many fractures present within the Committee is the difference in terms of interests between legislative and non-legislative regions. The third factor is a structural consequence of the first two factors above and is due to the heterogeneous composition of the Committee, a composition which results from another important divide, amplified after the 2004 and 2007 enlargements, namely the so called 'regional local divide' (Vandamme 2013). 
As Vandamme pointed out: 'Discussions over the distinct dominance of 'regional' over 'local' Europe started immediately in early 1992' however: 'It is an undisputed fact that the 2004 and 2007 rounds of EU enlargement had an impact on the composition of the Committee in terms of the local - regional divide. None of the new Member States maintain a federal or strongly decentralised state structure' (Vandamme 2013). ${ }^{\mathrm{VI}}$

The fourth reason is of course the legacy of what scholars call the 'territorial blindness' (Ipsen 1966; Weatherill and Bernitz 2005) of the EU. The 'legal' territorial blindness (Landesblindheit) of the Union towards the regions finds its confirmation in the wording of the Treaties (specifically in former Art. 10 TEC), where it is clear that the (original, at least) subjects of the Community legal order are the States, as bearers of the duty of cooperation in order to guarantee the effectiveness of supranational law. It is possible to find many confirmations of this approach both in the wording of the Treaties and in the case law of the Court of Justice of the EU (CJEU). This is also connected with the international law 'matrix' of the EU. For instance, the CJEU once argued that:

\footnotetext{
'It is apparent from the general scheme of the treaties that the term 'Member State', for the purposes of the institutional provisions and, in particular, those relating to proceedings before the courts, refers only to government authorities of the Member States of the European Communities and cannot include the governments of regions or autonomous communities, irrespective of the powers they may have. If the contrary were true, it would undermine the institutional balance provided for by the Treaties, which govern the conditions under which the Member States, that is to say, the States party to the Treaties establishing the Communities and the Accession Treaties, participate in the functioning of the Community institutions. It is not possible for the European Communities to comprise a greater number of Member States than the number of States between which they were established'. VII
}

Since the founding Treaties were signed by the Member States, they are the reference mark of the EU legal system and the holders of duties and rights. This is in a nutshell the reasoning of the CJEU in that case.

The 'indifference' of the EU with regard to the domestic territorial organisation of their Member States (an aspect of what scholars call territorial blindness) presents two sides, as Lenaerts pointed out: 
'EU law does not interfere with the internal division of powers between national and regional authorities within a Member State. Regions exercising their own constitutional powers must however do so in a manner consistent with EU law' (Lenaerts 2012).

This is the good side, which results in a sort of respect of the domestic vertical division of powers between center and periphery; we could call it 'territorial autonomy'.

However, there is also a negative side of the coin, represented by the impossibility of using the domestic separation of powers as a shield to justify non-compliance with EU law:

'A Member State is thus not entitled to hide behind the domestic division of powers or federal structure in order to avoid the CJEU making a finding of an infringement or to escape its obligation to bring such infringement to an end' (Lenaerts 2012).

In this sense this indifference towards the territorial organisation established by domestic constitutional law can be linked to the need for a uniform interpretation and application of EU law, as expressed in the famous (and ambivalent) Internationale Handelsgesellschaft decision. I am referring to the very famous point in which the CJEU argued that: "The validity of a Community measure or its effect within a Member State cannot be affected by allegations that it runs counter to either fundamental rights as formulated by the constitution of that State or the principles of its constitutional structure'. ${ }^{\mathrm{III}}$ Nevertheless, the CJEU has partially reconsidered its own position following the increasing importance of decentralisation processes within domestic systems in recent years (Saggio 2001; Thies 2011; Caruso 2011; Cygan 2014). After the Lisbon Treaty it has been argued that the principle of territorial blindness would have been partly overcome thanks (also) to the introduction of art. 4.2 TEU which expressis verbis refers to the regional and local levels:

'The Union shall respect the equality of Member States before the Treaties as well as their national identities, inherent in their fundamental structures, political and constitutional, inclusive of regional and local self-government. It shall respect their essential State functions, including ensuring the territorial integrity of the State, maintaining law and order and safeguarding national security. In particular, national security remains the sole responsibility of each Member State'. 
In the light of this and other important novelties introduced by the Reform Treaty (main text and Protocols), Fasone wondered whether it is now possible to speak of 'A Regionally Oriented EU' and noticed that these provisions appear 'finally to overturn the dogma of "regional blindness" which so far has characterised the EU approach towards the constitutional architecture of the Member States' (Fasone 2017: 57).

The fifth reason, perhaps the most intriguing one, is related to what Piattoni called the 'the problematic coexistence of functional and territorial representation in the EU' (Piattoni 2011). This leads us to the heart of the problem and to the schizophrenia that has characterised- since its inception - the CoR. In other words,

'The CoR was caught between two potentially conflicting visions: on the one hand, it was seen as a representative chamber of regional interests and minority nationalisms; on the other, it was seen as consultative committee of regional and local experts' (Piattoni and Schönlau 2015).

This also explains the limited success of the Committee, and why regional actors over the years have diversified their strategy, given the inefficiency of institutional channels of territorial representation and the progressive inclusion of broad civil society in new systems of consultation and cooperation with EU institutions' (Trobbiani 2016). For this scholar:

'Regions in Brussels are increasingly acting as actors of functional representation, in a cooperation with private stakeholders from within and outside their territories, partly redefining the concept of regional interest from a purely institutional one (MLG I) to a broader representation of the regional level as a unit of production (MLG II)' (Trobbiani 2016).

As we shall see in the next section, these are long standing problems that find their origin in the first years of the Committee (Falcone 2003); I now examine some pivotal moments in the history of the CoR.

\section{A Concise History of the Committee of the Regions}

\subsection{The Pre-Lisbon Scenario}


The relevant legal discipline of the CoR can be found in some provisions of the European Treaties (for instance Art. 13 TEU, ${ }^{\text {IX }}$ Arts. 305 - 307 TFEU $^{\mathrm{X}}$ ), in its Rules of Procedure $^{\mathrm{XI}}$ and in other pieces of legislation (see the Council Decision 2014/930/EU). ${ }^{\mathrm{XII}}$

This legal framework has been the product of a series of incremental adjustments, including for instance the relevant innovations of the Nice Treaty involving the structure of the Committee. ${ }^{\mathrm{XII}}$ As written at the beginning of this article many of the reasons behind the limited success of the CoR can be seen as long-standing problems; in this sense it is useful to briefly relate the history of the body to identify important turning points that have shaped the Committee that we know today. The Committee was the direct offspring of an enthusiastic era starting with the 1988 reform of the European structural funds and the introduction of the concept of partnership. This concept 'redesigned a system which was until then based on an almost total control by Member States of the process of allocation of funds' since 'the principle empowered the regional actors by allowing them to take part to the bargaining and decision-making phase' (Bailey and De Propris 2002). In that reform we can indeed find the origins of a period that led some authors to argue that the regions were going to become the most important actors in the EU by replacing the States. ${ }^{\text {XIV }}$ The 1988 reform paved the way for the beginning of the rhetoric of the 'Europe of Regions' which was subsequently replaced by another intriguing formula, that of a 'Europe with the Regions'. The Committee was introduced by the Maastricht Treaty and started in 1994, replacing the Consultative Council of Regional and Local Authorities established by Commission Decision 88/487 (Vandamme 2013; Simonato 2013). ${ }^{\mathrm{XV}}$

As scholars have pointed out, countries with legislative regions (Germany and Belgium above all) have had a crucial role in launching the Committee and giving it their imprint. ${ }^{\text {xVI }}$

This trend would be radically changed by the 2004 and 2007 enlargement, as discussed above, but also by the progressive politicisation of the members of the Committee which has steadily altered the dynamics of vote within the Committee, since 'the representatives are divided into political groups and have progressively gotten used to voting according to party lines rather than country of origin' (Trobbiani 2016). The 'local regional divide', which has grown after the enlargements, can be traced back to even earlier roots, as scholars pointed out (Vandamme 2013). 
If this phenomenon has produced fragmentation in a body which was supposed to act with a unitary voice, it is also true that within the regional component there has always been a range of positions. This also explains the launch of understandings and networks such as the REGLEG (The Conference of Regions with Legislative Power) in 2001 and the CALRE (supra) even earlier in 1997. This search for 'alternative channels to influence the EU institutions' included 'the possibility of some of the legislative regions to delegate a regional minister to the Council, transnational networks ... and through Members of the European Parliament that are elected in regional constituencies (and possibly with a stronger sensitivity to regional issues)' (Vandamme 2013).

Nevertheless, over the years the Committee has benefitted from a progressive reinforcement thanks to the expansion of the areas where its consultation is necessary (mandatory consultation), ${ }^{\mathrm{XVII}}$ or possible (voluntary consultation), and to the increase of its budget. The Lisbon Treaty introduced important innovations in this respect. Nowadays the CoR acts in a space characterised by the coexistence of different potential channels and fora that could be used by regions. This has led to the need to rethink its role, as the partnership concluded with CARLE and REGLEG confirms.

\subsection{The Importance of the Lisbon Treaty}

Lisbon did not give the CoR the status of a Union institution, but however granted it important powers, especially in respect of changes introduced to reinforce the principle of subsidiarity.

The literature on subsidiarity is massive (Estrella 2002; Syrpis 2004; Davies 2006a; Schütze 2009; Fasone 2013) and there is no need to rehearse it for the purpose of this article. However, it is possible to argue that one of the goals of the Lisbon Treaty was to strengthen the principle, and this has been done by clarifying the competences of the EU and by introducing some political safeguards capable of ensuring its - so to say physiological functioning. Indeed, the subsidiarity principle, on the one hand, needs an arrangement of competences at least tending towards a clear sharing of tasks, and, on the other hand, also presupposes an 'integrated' system like, for example, that of a federal arrangement of a cooperative type (Schütze 2009). As a matter of fact, the principle, as regulated in Art. 5.3 TEU, refers to a relationship between two institutional actors (a lower actor, the 'regional and local level', and a higher actor, the 'central level') sharing the same 
power. However, the exercise of this power is preferentially given to the subject which is closer to the citizens (i.e. the regional or local level). Scholars usually label this first instance as the negative side of subsidiarity since it implies the duty of non-intervention by the centre. At the same time, this principle allows for the possibility for the centre to replace the 'peripherical actor' if the same power can be exercised in a better or in a more efficient way by the higher subject (the Union). Against this background subsidiarity works as an elevator (Bin 2002, Panara 2015) with regard to certain fungible acts that can be exercised by two institutional subjects and the centripetal substitution and exercise of this power can be caused only by an objective impossibility to 'sufficiently' carry out the requested action for the peripherical actor. Another important fact is that such an impossibility to carry out the functions must be temporal. In this respect, it has been pointed out that the subsidiarity principle works, actually, as a criterion for shifting, although not in a definitive way, the level that is supposed to intervene (Massa Pinto 2003). Moreover, because of its constitutional relevance, it also serves as an element of flexibility in the system (Bin, 1999).

This would explain why, within the Community context, subsidiarity has operated as a 'method of policy centralisation' (Davies 2006b) rather than as a validating factor for decentred realities, in the absence of a formal catalogue of competences. Subsidiarity and competence are not, nevertheless, in a relationship of identity: in fact, it has been said that the principle of subsidiarity is not intended so much for an a priori formal allocation of competences, but rather for an a posteriori legitimation of the exercise of competences beyond those formally attributed (Massa Pinto 2003).

Subsidiarity has successfully operated in a context such as Germany, which does not define competences in a finalistic manner (Carrozza 2003) as the European Treaties did in the pre-Lisbon phase. This worrying mingling of legal styles explains the destabilisation factor that may be introduced by the subsidiarity principle, and that is why when it was introduced Toth described it as 'totally alien' to the EU, since it 'contradicts the logic, structure and wording of the founding treaties and the jurisprudence of the European Court of Justice' (Toth 1993). This is mainly because of its 'surreptitious' substitution of the flexibility clause, which has allowed the Union (and before it the Community) to acquire 'slices of competence', indirectly instrumental to the achievement of the declared objectives, without the procedural guarantee of unanimity. 
The matter for discussion remains the high level of political discretion which would characterise the application of such a principle, because of the political nature of the control base and the difficult verification of the efficiency and context of the action. This reading has been confirmed by the case law of the CJEU which has traditionally avoided dealing with the issue head on. More recently scholars have noticed some progress in this field, but the approach of the CJEU has remained quite hesitant (Öberg 2017a). The most telling example of this trend is an old case - United Kingdom v. Council VVIII $^{\mathrm{N}}$ - where de facto the subsidiarity control was seen as a kind of extrema ratio exploitable solely in the case of manifest error or misuse of power. More generally, according to the CJEU, since the control on subsidiarity touches the sensitive field of the legislative discretion, this reveals the 'political' nature of this test. Keeping this in mind, one can understand the rationale behind the introduction of the EWM. This case law explains why in the last few years all attempts to reform the principle of subsidiarity have attempted to emphasise the procedural side of such a control, entrusting a crucial role to the national legislatures, as the provisions included in the (defunct) Constitutional Treaty and in the Lisbon Treaty demonstrate. The only way to limit legislative discretion seems to be to impose procedural guarantees such as those contained in the Protocol on the application of the principles of subsidiarity and proportionality. Moreover, a similar procedural shift can be found even in the case law of the CJEU (Öberg 2017b).

As a result, the EWM, as a form of political monitoring, was provided in that Protocol. This idea confirms the deference shown by the CJEU towards the legislatures; since subsidiarity involves political control, the best option is to entrust its control to the political/legislative competitors of the European Parliament and Council: the national parliaments, tasked with the mission of watchdog of subsidiarity. This idea relies on the view that the primary democratic organs in Europe are the national parliaments but, as the German Constitutional Court recently pointed out in its Lissabon Urteil, ${ }^{\mathrm{XIX}}$ sometimes the national parliaments underestimate this role, giving up competences or not fully understanding the importance of their role.

In this respect the Lisbon Treaty offers some important elements in this field: the codification of a list of competences (although it is not a hard list) and that of the principle of sincere cooperation. 
As we saw, subsidiarity and competence are two distinct yet strongly related concepts and, in this respect, a detailed distribution of powers in the configuration of the Union might be useful for the CJEU, since it might help the latter to implement the constitutional nature of the subsidiarity principle under lesser political pressure. However, perhaps the most important innovation is represented by the principle of loyal cooperation (Art. 4.3 TEU). ${ }^{\mathrm{xx}}$ One could argue that this principle was already present in the spirit of former Art. 10 TEC, ${ }^{\mathrm{XXI}}$ but in that case the provision focused much more on the loyalty duty of the States; while, according this new text, the loyalty duty is bi-lateral, involving the necessity to respect national identities 'inherent in their fundamental structures, political and constitutional, inclusive of regional and local self-government'. XXII The combination of the recognition of the regional and local level as stated in Art. 4.2 TEU and this new understanding of the principle of loyal cooperation as stated in Art. 4.3 TEU justifies the (potentially) important role granted to the CoR in the preservation of the principle of subsidiarity $^{\mathrm{XXII}}$.

As anticipated in the very first part of this work, in a recent resolution the CoR threatened to use, for the first time, its new power granted by the Lisbon Treaty. The resolution is about a Commission's proposal for a regulation aimed at amending the Common Provisions Regulation (EU) No 1303/2013 of 6 December 2017. XxIv

Within the text of its proposal the Commission itself declared that this initiative was consistent with the subsidiarity principle, 'to the extent that it provides continued increased support through cohesion policy for certain Member States which opt for the use of the performance reserve for structural reform support. This mechanism needs to be established at European level., xxv

The resolution of the CoR followed an initiative of its political groups, after having recalled several previous opinions, ${ }^{\mathrm{XXV}}$ contained a direct attack on the Commission's proposal by arguing that:

'The reasoning given for compliance with the subsidiarity principle, since the objective of cohesion policy, as implemented by the European Structural and Investment Funds for which the Common Provisions Regulation (CPR) provides the overall legal framework, is not to support structural reforms in the Member States but to reduce disparities between the levels of development of the various regions and the backwardness of the least favoured regions'. XxvII 
In addition, the CoR argued that this proposal would risk distorting the real goals of the EU cohesion policy since the latter 'does not include an obligation to finance general structural reforms in the Member States ${ }^{\text {XXVIII }}$ but to 'to reduce disparities between the levels of development of the various regions and the backwardness of the least favoured regions'. XxIx

In order not to violate the principle of subsidiarity, moreover, the proposal should clarify in rigorous terms the exact 'notion and scope of 'structural reforms' eligible for European financial support' ${ }^{\mathrm{xx}}$ On a different note, according to the Committee, this proposal also undermined the principles of partnership and multi-level governance. Finally, the CoR added that:

'The opt-in clauses and voluntary participation in an EU scheme cannot be used as an argument to claim that the proposal has no subsidiarity relevance as long as this scheme involves EU funding aimed at achieving objectives set in the Treaties that are relevant to all EU Member States. Indeed, any EU funding must be granted with a view to objectives set in the EU Treaties and have a legal basis directly relating to the objectives that it is intended to achieve'. ${ }^{x x x}$

In light of these considerations the resolution sent a warning to the Commission by concluding that the CoR 'stands ready to make full use of its prerogative to challenge the legislative act before the Court of Justice of the European Union'. XxxII

To my knowledge the CoR has not yet concretised this menace but it is evident from these lines that it would be eager to do that if necessary.

\section{Final Remarks}

In this article I tried to explain the main reasons behind the limited success - or, according to another terminology - the failure of the CoR, looking at five main reasons: the polysemous notion of region in EU law; the legacy of the Landesblindheit, the horizontal diversity present at national constitutional level with regard to the powers and competences of the regions; the heterogeneous composition of the Committee; and the coexistence of functional and territorial representation in the Committee. I then tried to find the origin of these factors in the history of the Committee by identifying some turning points in order to 
show how these are long standing problems that have always accompanied the Committee and that have later been amplified by the 2004 and 2007 rounds of enlargement.

As said, the Lisbon Treaty presents both continuity and discontinuity with the past since, on the one hand, it has contributed to the expansion of the areas where the opinion of the Committee is compulsory, and its budget, respecting a trend that started with the Amsterdam Treaty. On the other hand, it has also invested a lot in the Committee by conferring new powers to it, including the status of semi-privileged plaintiff.

In light of this, some have called for the abolition of the Committee, including, recently, a motion for a European Parliament resolution on the abolition of the CoR

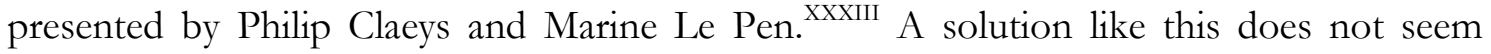
feasible and realistic nowadays, although it has been said that:

'Given the European Parliament's increased role in shaping EU legislation, the CoR's envisioned role is also no longer a valid justification for its existence. A growing number of officials and politicians are realising that having two committees which together cost $€ 215 \mathrm{~m}$ but which deliver no clear added value is simply unsustainable in such economically challenging times' (Open Europe 2012).

These comments do not take into account that, actually, according to some studies 'opinions of the CoR do often produce effects in particular vis-a-vis the European Commission. Especially in certain areas of policy, the Commission proves quite willing to take on board suggestions of the Committee' (Vandamme 2013). ${ }^{\text {xxIv }}$

The second proposal frequently evoked concerns the creation of two separate chambers devoted, respectively, to the representatives of regions and to those of local authorities. The model in this sense would be represented by the Congress of Local and Regional Authorities of the Council of Europe, but the added value of this proposal has been questioned by scholars for at least two reasons. First of all because the growing importance of political groups ${ }^{\mathrm{XxxV}}$ within the Committee has perhaps become more important than the regional - local divide, second for the doubts expressed about a solution like this in light of the lesson coming from the Council of Europe, on the wasteful duplication of activities. ${ }^{\text {xxxvI }}$ 
However, it is also true that there a need for new equilibria within the Committee, if once the fact that the top positions are still held by representatives of regions in spite of the growing relevance of the local level, especially after the 2004 and 2007 enlargements. XxxvII

An intervention in the so called 'double mandate' of its alternate members has been also suggested, but it is undeniable that this contributes to the legitimacy of the CoR by somehow reducing the distance between the EU and its territorial actors. ${ }^{\text {xxxvIII }}$

Finally, the 'promotion' of the Committee from body to full-fledged institution has once again been suggested, but I do not think this would really solve the ambiguities present in its functioning and activity. Instead of claiming an 'institutional upgrade' the Committee should take advantage and exploit the new window of opportunity offered by the Lisbon Treaty. In this sense the post-Lisbon phase should be seen as a sort of waiting room to test how a reinforced - in terms locus standi before the Court of Justice- will interpret its role.

If the Committee was conceived - in a particular cultural and political atmosphere as recalled in the second part of this contribution - as a privileged arena to give a voice to the regions, nowadays the situation has changed, since regions tend to think more in terms of functional representation and this makes the Committee part of a broader constellation.

At the same time the partnership concluded with the legislative regions' transnational networks (CALRE and REGLEG) shows the pivotal role that the CoR still plays for the regional level:

'Yet, they also stressed that this form of horizontal cooperation between the (self-proclaimed) legislative regions should not be regarded as the evidence that the CoR is becoming increasingly passé for them. These same respondents stressed the fact that the CoR has concluded strategic partnership agreements with both REGLEG and CALRE so as to maximise the complementarity between these two networks. The Committee was said to maintain its 'main hub' function for both these selective networks. In this regard attention was also drawn to the fact that both CALRE and REGLEG are networks that lack the resources such as those available to the CoR and that the yearly rotating presidency of these two networks sometimes hampers their effectiveness (depending on the presidency). The institutional embedding in the CoR of CALRE and REGLEG is thus welcomed by the legislative regions.' (Vandamme 2013). 
What Vandamme wrote five years ago is still absolutely valid even in a context where regions have progressively experimented alternative strategies and channels to express their concerns and where the idea itself of territorial representation has been accompanied by the progressive rise of a regional interest in 'functional representation' (Trobbiani 2016). It is up to the CoR to adapt itself to this new context, by renouncing its claim over a monopolistic representation of the subnational dimension in the EU, and accepting that it must transform itself into the most important piece of a variegated representative puzzle where regions can modulate their voice depending on the concrete challenge they want to address.

\footnotetext{
* Associate Professor of Comparative Public Law at the Scuola Universitaria Superiore Sant'Anna, Pisa. I would like to thank Giacomo Delledonne, Cristina Fasone, Diane Fromage, Sara Iglesias Sánchez and the anonymous referees for their help and comments.

I See the official website: http://cor.europa.eu/en/Pages/home.aspx. For an overview see: http://www.europarl.europa.eu/atyourservice/en/displayFtu.html?ftuId=FTU 1.3.14.html.

II See the official website: https://www.calrenet.eu/.

III Art. 263 TFEU: 'The Court of Justice of the European Union shall review the legality of legislative acts, of acts of the Council, of the Commission and of the European Central Bank, other than recommendations and opinions, and of acts of the European Parliament and of the European Council intended to produce legal effects vis-à-vis third parties. It shall also review the legality of acts of bodies, offices or agencies of the Union intended to produce legal effects vis-à-vis third parties. It shall for this purpose have jurisdiction in actions brought by a Member State, the European Parliament, the Council or the Commission on grounds of lack of competence, infringement of an essential procedural requirement, infringement of the Treaties or of any rule of law relating to their application, or misuse of powers.

The Court shall have jurisdiction under the same conditions in actions brought by the Court of Auditors, by the European Central Bank and by the Committee of the Regions for the purpose of protecting their prerogatives.

Any natural or legal person may, under the conditions laid down in the first and second paragraphs, institute proceedings against an act addressed to that person or which is of direct and individual concern to them, and against a regulatory act which is of direct concern to them and does not entail implementing measures.

Acts setting up bodies, offices and agencies of the Union may lay down specific conditions and arrangements concerning actions brought by natural or legal persons against acts of these bodies, offices or agencies intended to produce legal effects in relation to them.

The proceedings provided for in this Article shall be instituted within two months of the publication of the measure, or of its notification to the plaintiff, or, in the absence thereof, of the day on which it came to the knowledge of the latter, as the case may be'.

IV Art. 8 Protocol 2: 'The Court of Justice of the European Union shall have jurisdiction in actions on grounds of infringement of the principle of subsidiarity by a legislative act, brought in accordance with the rules laid down in Article 263 of the Treaty on the Functioning of the European Union by Member States, or notified by them in accordance with their legal order on behalf of their national Parliament or a chamber thereof. In accordance with the rules laid down in the said Article, the Committee of the Regions may also bring such actions against legislative acts for the adoption of which the Treaty on the Functioning of the European Union provides that it be consulted.

v For the text of the White Paper go to: http://cor.europa.eu/it/activities/governance/Pages/white-papeon-multilevel-governance.aspx. See also Valcárcel Siso 2014.

VI Besides that, there is also another important dived that has been introduced at that time, namely the East West divide: 'Based on the outcome of the interviews, one effect from the expansion of the EU towards the east and south in 2004 and 2007 did transpire. Several respondents voiced concerns about the large number of regional and local authorities from the new Member States that are, in terms of administrative capacity, relatively weakly developed in comparison to their 'Western' counterparts. Thus, for the functioning of the Committee the 2004 and 2007 accessions were deemed to have a large impact although not, as was the hypothesis of this contribution, in relation to the local-regional divide. Rather, one might speak of the 'East - West' divide in this respect. This comes especially to the fore when the Committee is to advice on the issues of
} 
implementation/application of EU law. Since the vast majority of EU legislation is to be implemented on the regional and/or the local level, there is an interest in this issue across all levels of sub-national government. Yet, whereas the more highly developed entities (and these may range from federated states to municipalities) quite often prefer that the responsibility for implementation I application is diverted to them, the sub-national entities of the new Member States often prefer EU legislation to call for central implementation by the Member State' authorities as they often lack the expertise and / or the means to implement new EU policies' (Vandamme 2013).

VII CJEU, Case C-95/97, Région wallonne v Commission of the European Communities, ECR, 1997, I-01787 VIII CJEU, 11/70, Internationale Handelsgesellschaft, ECR 19701125.

IX Art. 13 TEU: '4. The European Parliament, the Council and the Commission shall be assisted by an Economic and Social Committee and a Committee of the Regions acting in an advisory capacity'.

x Art. 305 TFEU: 'The number of members of the Committee of the Regions shall not exceed 350.

The Council, acting unanimously on a proposal from the Commission, shall adopt a decision determining the Committee's composition. The members of the Committee and an equal number of alternate members shall be appointed for five years. Their term of office shall be renewable. The Council shall adopt the list of members and alternate members drawn up in accordance with the proposals made by each Member State. When the mandate referred to in Article 300(3) on the basis of which they were proposed comes to an end, the term of office of members of the Committee shall terminate automatically and they shall then be replaced for the remainder of the said term of office in accordance with the same procedure. No member of the Committee shall at the same time be a Member of the European Parliament.

Art. 306 TFEU: 'The Committee of the Regions shall elect its chairman and officers from among its members for a term of two and a halfyears. It shall adopt its Rules of Procedure. The Committee shall be convened by its chairman at the request of the European Parliament, the Council or of the Commission. It may also meet on its own initiative'.

Art. 307 TFEU: 'The Committee of the Regions shall be consulted by the European Parliament, by the Council or by the Commission where the Treaties so provide and in all other cases, in particular those which concern cross-border cooperation, in which one of these institutions considers it appropriate.

The European Parliament, the Council or the Commission shall, if it considers it necessary, set the Committee, for the submission of its opinion, a time limit which may not be less than one month from the date on which the chairman receives notification to this effect. Upon expiry of the time limit, the absence of an opinion shall not prevent further action. Where the Economic and Social Committee is consulted pursuant to Article 304, the Committee of the Regions shall be informed by the European Parliament, the Council or the Commission of the request for an opinion. Where it considers that specific regional interests are involved, the Committee of the Regions may issue an opinion on the matter. It may issue an opinion on its own initiative in cases in which it considers such action appropriate.

The opinion of the Committee, together with a record of the proceedings, shall be forwarded to the European Parliament, to the Council and to the Commission'.

XI Available at the following link: https://cor.europa.eu/en/documentation/Documents/Rules-ofProcedure-of-the-Committee-of-the-Regions/EN.pdf. See also the Council Decision 2014/930/EU https://eur-lex.europa.eu/legal-content/EN/TXT/?uri=CELEX\%3A32014D0930.

XII Council Decision 2014/930/EU
content/EN/TXT/?uri=CELEX\%3A32014D0930.

XIII 'It states that members of the CoR must hold a local or regional electoral mandate or be politically accountable to an elected local or regional assembly. It also lays down that members can now be appointed by qualified majority vote at the Council, rather than requiring unanimous backing. Membership of the CoR will terminate automatically if members lose the mandate on the basis of which they are appointed. The Treaty sets the maximum number of members of the CoR at 350, with the number of members standing at 317 for an EU of 25 countries' (Committee of the Regions 2010)

XIV As Loughlin wrote: 'Some enthusiasts proclaimed in the early nineties that the regions were to become the most important 'units' of the European integration process5 even bypassing the Member States by 'bringing together federalist and regionalist opponents of the nation state' (Loughlin 2002).

XV Commission Decision 88/487/EEC of 24 June 1988 OJ 1988, L 247, 23, available at: http://eurlex.europa.eu/legal-content/EN/TXT/?uri=CELEX\%3A31988D0487.

$\mathrm{XVI}$ 'The historic significance of the EU's legislative regions for the CoR as a EU body cannot easily be overestimated. Without them the EU, in particular the German Länder, the Belgian Régions and Communautés and the Spanish Comunidades Autonomas, the CoR would never have seen the light of day. Consequently their imprint on the Committee in its early days was considerable. This drives home the main reason to revisit the CoR: the dramatic geographic expansion of the EU after 2004 and 2007 (Vandamme 2013).

XVII See Arts. 165 TFEU, 167 TFEU, 168 TFEU, 172 TFEU, 175, 177 and 178 TFEU.

XVIII CJEU, C-84/94 United Kingdom v. Council, ECR, 1996 I-5755. 
XIx Lisbon Case, BVerfG, 2 BvE 2/08 from 30 June 2009, available at: http://www.bundesverfassungsgericht.de/entscheidungen/es20090630 2bve000208.html.

xx Art. 4 TEU: '3. Pursuant to the principle of sincere cooperation, the Union and the Member States shall, in full mutual respect, assist each other in carrying out tasks which flow from the Treaties.

The Member States shall take any appropriate measure, general or particular, to ensure fulfilment of the obligations arising out of the Treaties or resulting from the acts of the institutions of the Union.

The Member States shall facilitate the achievement of the Union's tasks and refrain from any measure which could jeopardise the attainment of the Union's objectives'.

XXI Art. 10 TEC: 'Member States shall take all appropriate measures, whether general or particular, to ensure fulfilment of the obligations arising out of this Treaty or resulting from action taken by the institutions of the Community. They shall facilitate the achievement of the Community's tasks. They shall abstain from any measure which could jeopardise the attainment of the objectives of this Treaty'.

xxII Art. 4. TEU.

xxIII The CoR has a key role in this sense and its task builds upon the expertise created thanks to the 'Subsidiarity Monitoring Network' that was launched in April 2007 (https://portal.cor.europa.eu/subsidiarity/thesmn/Pages/default.aspx). In 2013 the Committee of the Regions also published its first 'Subsidiarity Work Programme' and, finally, three members of the Task Force on Subsidiarity, Proportionality and 'Doing Less More Efficiently' come from the CoR. This task force was established by Decision C(2017)7810 of the President of the Commission (https://ec.europa.eu/info/sites/info/files/2017-c-7810-president-decision en 1.pdf) and has the mission to propose "how the EU could take better into account the principles of subsidiarity and proportionality, both with regard to the attribution and the exercise of its competences" (https://portal.cor.europa.eu/subsidiarity/TaskForce/Pages/welcome.aspx). Another important network is REGPEX. 'This network has a more exclusive character compared with the SMN as it provides a database for only those governments and parliaments of regions that have legislative powers. The REGPEX partners submit opinions on EU draft legislative acts and exchange information with their counterparts' (Granat, 2018)

Xxiv For the text of the European Commission's proposal go to: http://eur-lex.europa.eu/legalcontent/EN/TXT/?uri=CELEX:52017PC0826 and for the text of the CoR's resolution: https://memportal.cor.europa.eu/Handlers/ViewDoc.ashx?doc=COR-2017-06173-00-00-PRES-TRA-

EN.docx https://memportal.cor.europa.eu/Handlers/ViewDoc.ashx?doc=COR-2017-06173-00-00-PRESTRA-EN.docx.

xxvProposal for a REGULATION OF THE EUROPEAN PARLIAMENT AND OF THE COUNCIL amending Regulation (EU) No 1303/2013 of the European Parliament and of the Council of 17 December 2013, available at: http://eur-lex.europa.eu/legal-content/EN/TXT/?uri=CELEX:52017PC0826.

xxvi Namely the CoR opinions : 1) on 'the proposal by the Commission for a General Regulation on the funds covered by the Common Strategic Framework of 4 May 2012'; 2) on 'the Structural Reform Support Programme for the period 2017 to 2020 of 8 April 2016'; 3) on 'the future of cohesion policy beyond 2020 "For a strong and effective European cohesion policy beyond 2020" of 12 May 2017'; 4) on 'Improving the governance of the European Semester: a Code of Conduct for the involvement of local and regional authorities of 11 May 2017'; 5) on 'the Reflection Paper on the Deepening of the Economic and Monetary Union by 2025 of 1 December 2017'.

XXVII https://memportal.cor.europa.eu/Handlers/ViewDoc.ashx?doc=COR-2017-06173-00-00-PRES-TRAEN.docx.

XXVIII Ibidem.

xxix Ibidem.

xxx Ibidem.

xxxi Ibidem.

xxxiI Ibidem.

xxxiII Available

at:

http://www.europarl.europa.eu/sides/getDoc.do?pubRef=//EP//TEXT+MOTION+B7-2014-0270+0+DOC+XML+V0//EN.

xxxiv See also Neshkova 2010.

$\mathrm{XxxV}$ 'Another conclusion that could be drawn from the responses was that over the years the regional-local division within the CoR was gradually overshadowed by the political divisions in political groups' (Vandamme 2013).

XxxvI Second because as empirical research has suggested: 'Hereby the example of the Congress of Local and Regional Authorities of the Council of Europe was invoked. This body has been sub-divided into two separate chambers... 'the interviewee 
in practice this resulted in "different people ending up doing the same work" (Vandamme 2013).

XXXVII 'Yet, the prominent role of the legislative regions who form after the 2004 and 2007 enlargements of the EU a 'numerical minority' in the $\mathrm{CoR}$ also leads one to question the Committee's representative function. In this context, attention was also drawn to the fact that many key positions in the CoR are still beld by politicians from the legislative regions despite the change in the Committee's composition after the enlargements' (Vamdamme 2013).

XXXVII 'An exceptional aspect of the CoR is the 'double mandate' for its (alternate) members. The (alternate) members of the $\mathrm{CoR}$ are appointed by the Council of Ministers of the EU. However, they lose their (alternate) membership of the CoR if they lose the national mandate. On the one hand, this rule seems to strengthen the legitimacy of the CoR as a EU body. Yet, on the other hand, it also seems to cause (practical) problems' (Vandamme 2013).

xxxvII Trobbiani 2016.

\section{References}

- Bailey David and De Propris Lisa, 2010, 'EU Structural Funds, Regional Capabilities and Enlargement: Towards Multi-Level Governance?', Journal of European Integration, XXIV(4): 303-324.

- Bin Roberto, 1999, 'I decreti di attuazione della «legge Bassanini» e la "sussidiarietà verticale", in Rinella Angelo, Coen Leopoldo and Scarciglia Roberto (eds), Sussidiarietà e ordinamenti costiturionali, Cedam, Padova, 1999, 183-193.

- Bin Roberto, 2002, 'La funzione amministrativa nel nuovo titolo V della Costituzione', Le Regioni, XXX(2-3): 365-382.

- Brusis Martin, 2002, 'Between EU requirements, competitive politics and national traditions: recreating Region in the Accession Countries of Central and Eastern Europe', Governance, XV(4): 531-559.

- Carrozza Paolo, 'Le 'materie': uso delle tecniche di enumerazione materiale delle competenze e modelli di riferimento del 'regionalismo di esecuzione' previsto dal nuovo Titolo V della Costituzione', in Ferrari Giuseppe Franco and Parodi Giampaolo (eds), La revisione costiturionale del titolo $V$ tra nuovo regionalismo e federalismo. Problemi applicativi e linee evolutive, Cedam, Padova, 69-124.

- Caruso Daniela, 2011, 'Direct Concern in Regional Policy: The European Court of Justice and the Southern Question', European Law Journal; XVII(6): 804-827.

- Committee of the Regions, 2010, The Committee of the Regions: Key dates, Committee of the Regions, Bruxelles, available at: http://cor.europa.eu/en/documentation/brochures/Documents/cdr-key-dates2010/EN.pdf.

- Conzelmann, Thomas, 2008, 'Towards a new concept of multi-level governance', available at: http://cor.europa.eu/en/activities/governance/Documents/Conzelmann.pdf.

- Cooper Ian, 2012, 'A 'Virtual Third Chamber' for the European Union? National Parliaments after the Treaty of Lisbon', West European Politics, XXXV(3): 441-465.

- Cygan Adam, 2014, 'The Regions Within Multi-Level Governance: Enhanced Opportunity for Improved Accountability?', The Maastricht Journal of European and Comparative Law, XXI(2): 265-280.

- Davies Gareth, 2006a, 'Subsidiarity: the wrong idea, in the wrong place, at the wrong time', Common Market Law Review: 63 et seq.

- Davies Gareth, 2006b, 'Subsidiarity as a Method of Policy Centralisation', Hebrew University International Law Research Paper No. 11-06, available at: http://papers.ssrn.com/sol3/papers.cfm?abstract id=921454.

- $\quad$ Estella Antonio, 2002, The EU Principle of Subsidiarity and Its Critique, Oxford University Press, Oxford.

- Fabbrini Federico and Granat Katarzyna, 2013, 'Yellow card, but no foul: the role of the national parliaments under the subsidiarity protocol and the Commission proposal for an EU regulation on the right to strike', Common Market Law Review, L(1): 115-143.

- Falcone Vincenzo, 2003, 'Il Comitato delle Regioni: esperienze e prospettive', in D'Atena Antonio (ed), L'Europa delle autonomie. Le Regioni e l'Unione europea, Giuffrè, Milano, 247-254.

- $\quad$ Fasone Cristina, 2013, 'Competing Concepts of Subsidiarity in the Early Warning Mechanism', LUISS Guido Carli School of Government Working Paper No. SOG-WP4/2013, available at: https://papers.ssrn.com/sol3/papers.cfm?abstract id=2243503. 
- $\quad$ Fasone Cristina, 2017, 'Secession and the Ambiguous Place of Regions Under EU Law', in Closa Carlos (ed), Secession from a Member State and Withdrawal from the European Union Troubled Membership, Cambridge University Press, Cambridge.

- Gamper, Anna, 2005, “A “Global Theory of Federalism”: The Nature and Challenges of a Federal State’, German Law Journal, VI(10): 1297-1318.

- Granat Katarzyna, 2018, The Principle of Subsidiarity and its Enforcement in the EU Legal Order The Role of National Parliaments in the Early Warning System, Hart Publishing, Oxford.

- Hagemann Sara and Høyland Bjørn, 2010, 'Bicameral Politics in the European Union', Journal of Common Market Studies, XLVIII(4): 811-833.

- Hettne Björn and Söderbaum, Frederik, 2000, 'Theorizing the Rise of Regionness', New Political Economy, V(3): 457-472.

- Ipsen Hans Peter, 1966, 'Als Bundesstaat in der Gemeinschaft', in Caemmerer Ernst von., Schlochauer Hans Jürgen and Steindorff Ernst (eds), Probleme des Europäischen Recht. Festschrift für Walter Hallstein zu seinem 65. Geburstag, Klostermann, Frankfurt am Main, 248-265.

- Iurato Giovanna, 2006, 'L’UE e la rappresentanza territoriale regionale', Le Regioni, XXXIV(4): 679710.

- Lenaerts Koenraad, 2012, 'The law of the European Union and the exercise by regions of their tax powers', in Flemish Department of Finance and Budget (ed), Fiscal Federalism in the European Union: EU Presidency Seminar, Groep De Boeck Departement Larcier, Gent, 15-38.

- $\quad$ Loughlin John, 1994, 'Nation, state, and region in Western Europe', in Bekemans Léonce (ed), Culture: Building stone for Europe 2002: Reflections and perspectives, Peter Lang Publishing, Bruxelles, 229-248.

- Massa Pinto Ilenia, 2003, Il principio di sussidiarietà- Profili storici e costituzionali, Jovene, Napoli.

- Neshkova Milena, 2010, 'The Impact of subnational interests on supranational regulation', Journal of European Public Policy, XVII(8): 1193-1211.

- $\quad$ Norton Philip, 2006, 'How many bicameral legislatures are there?', The Journal of Legislative Studies, X(4): $1-9$.

- $\quad$ Öberg Jacob, 2017a, 'Subsidiarity as a Limit to the Exercise of EU Competences', Yearbook of European Law, XXXVI(1): 391-420.

- Öberg Jacob, 2017b, 'The Rise of the Procedural Paradigm: Judicial Review of EU Legislation in Vertical Competence Disputes', European Constitutional Law Review, XIII(2): 248-280.

- Open Europe, 2012, 'The Rise of the EU Quangos', available at: http://archive.openeurope.org.uk/Content/Documents/Pdfs/RiseoftheEUquangos2012.pdf.

- Palermo Francesco, 2005, La forma di Stato dell'Unione europea. Per una teoria costituzionale dell'integrazione sovranazionale, Cedam, Padova.

- Panara Carlo, 2015, The Sub-national Dimension of the EU: A Legal Study of Multilevel Governance, Springer Verlag, Heidelberg.

- Piattoni Simona, 2009, 'The Committee of the Regions White Paper on Multilevel Governance: Some Reflections', available at: http://cor.europa.eu/en/activities/governance/documents/3e92ec7e-8a35-495aaee8-b23b12783a6a.pdf.

- Piattoni Simona, 2011, 'The Problematic Coexistence of Functional and Territorial Representation in the EU', Journal of European Integration, XXXIII(4): 369-384.

- Piattoni Simona and Schönlau Justus, 2015, Shaping EU Policy from Below: EU Democracy and the Committee of the Regions, Edward Elgar, Chelthenam.

- Russo Anna Margherita, 2012, 'La Distribución Territorial del Poder en los Estados Miembros de la Unión Europea: El 'Federalizing Process’ en Acción', Revista de Derecho Constitucional Europeo, no. 17: 385-468.

- Saggio Antonio, 2001, 'La responsabilità dello Stato per violazione del diritto comunitario', Danno e responsabilità, VI(3): 223-242.

- Schütze Robert, 2009, From Dual to Cooperative Federalism. The Changing Structure of European Law, Oxford University Press, Oxford.

- Simonato Alessandro, 2013, 'Il rapporto tra Regioni, Stato ed UE alla luce della crisi economica, dell'attualità istituzionale, del dibattito sul paradigma della multilevel governance', federalismi.it. Rivista di diritto 
pubblico italiano, comparato, europeo, XI(9), available at: http://federalismi.it/nv14/articolodocumento.cfm?artid $=22327$.

- $\quad$ Skoutaris Nikos, 2012,'Federalism: The European Union's Uncommon Principle’, paper presented at York University, on 6 March 2012, http://euce.apps01.yorku.ca/2012/02/lecture-federalism-the-europeanunions-uncommon-principle-march-6-2012/.

- $\quad$ Syrpis Phil, 2004, 'In Defence of Subsidiarity', Oxford Journal of Legal Studies, XXIV(2): 323-334.

- Thies Anne, 2011, 'The Locus Standi of the Regions before Community Courts', in De Becker Alexander and Panara Carlo (eds), The Role of the Regions in the European Governance, Springer Verlag, Heidelberg, 25-53.

- Toth Akos, 1993, 'The Principle of Subsidiarity in the Maastricht Treaty', Common Market Law Review, XXIX(6): 1079-1105.

- Trobbiani, Riccardo, 2016, 'European regions in Brussels: towards functional interest representation?', Bruges Political Research Papers 53/2016, available at: https://www.coleurope.eu/system/files force/researchpaper/wp53 trobbiani.pdf?download=1.

- Valcárcel Siso Ramón Luis, 2014, Towards a European Senate of the Regions Report on the Future of the Committee of the Regions: 50 Recommendations, Committee of the Regions, Bruxelles, available at: http://cor.europa.eu/en/documentation/brochures/Pages/towards-a-european-senate-of-the-regions.aspx.

- Vandamme Thomas, 2013, 'Still the Committee of 'Legislative Regions'? On Heterogeneity, Representation and Functionality of the Committee of the Regions after 2004', Amsterdam Centre for European Law and Governance Working Paper Series 2013-03, available at: https://papers.ssrn.com/sol3/papers.cfm?abstract id=2229734.

- Weatherill Stephen and Bernitz Ulf (eds), 2005, The role of regions and subnational actors in Europe, Hart Publishing, Oxford. 